\title{
HOW DO LAND USE REGULATIONS INFLUENCE INDUSTRIAL LAND PRICES? EVIDENCE FROM CHINA
}

\author{
Fan TU (D), Shuangling ZOU (D), Ran DING \\ School of Management, Zhejiang University of Technology, 310023, Hangzhou, China
}

Received 01 March 2020; accepted 01 October 2020

\begin{abstract}
Due to low industrial land prices and inefficiently used industrial land, China's central government has reformed land regulations in order to promote more market-oriented industrial land. Considering the differences in land management between developed and developing countries, this study aims to investigate the impact of land use regulations on industrial land prices in China and the effect of market-oriented reforms of industrial land policy. Measures that capture multiple dimensions of land use regulation tools are incorporated into OLS models based on a micro dataset from 1999 to 2016 that covers Jiaxing City in Eastern China. The results show that (1) The land policy implemented in 2006 to promote industrial land marketization has had a very limited effect; (2) The impact of land supply on industrial land prices was decreased for land transferred through listings after 2006, which implies an immature marketization; (3) Zoning instruments has obvious effects on industrial land prices; (4) The results imply that the effect of land use regulations varies with firm ownership and development zones. The findings in this paper clearly show that the industrial land market should be more open and competitive and combined with a rational land supply to promote the market-oriented price mechanism.
\end{abstract}

Keywords: industrial land use, industrial land price, land use regulation, land use planning, land marketization, land use efficiency.

\section{Introduction}

Because of the accelerated economic development and rapid urbanization in China, land prices in Chinese cities are rapidly increasing. From 2000 to 2017, residential and commercial land prices increased by 7.1 times and 4.53 times, respectively, but industrial land prices increased by only 1.79 times. In a survey conducted in Hangzhou, the capital of Zhejiang province, land prices accounted for only one-third of the total cost of clean land. The most direct impact of the low industrial land price is the low efficiency of industrial land use, which is manifested in the fact that some industrial land is not fully utilized and that the overall output efficiency is low. Among the 520 national-level development zones, more than 30\% (34.61\%) utilized $70 \%$ to $90 \%$ of their land. Strengthening the supervision of land use and increasing the retransfer of stock land are necessary.

The Chinese government has hoped to improve the efficiency of industrial land and accelerate the marketization of industrial land allocation through reforming industrial land regulations. Before 2006, industrial land was trans- ferred through negotiation between the government and enterprises at a very low price and was not transferred through the open market. In 2006, the State Council issued its Notice on Strengthening Relevant Issues Concerning Land Regulation and Control, which required industrial land to be transferred from the government to industrial firms through open channels, including tender, auction and listing. The minimum transfer price is also enforced to prohibit industrial land from selling at a low price. Moreover, the zoning code, including the floor area ratio (FAR) and percentage of built area (density), is required to be announced clearly. Since this policy was implemented, negotiation types of industrial land transfers are limited.

Despite many studies on the factors that influence land use regulation for residential properties, studies focusing on industrial properties are limited and mostly base on data from developed countries (Callahan, 2017; Saz-Salazar \& Leandro, 2005). In terms of research on industrial land prices, Chinese scholars have initiated an upsurge in research, mostly along two angles. The first angle is an

*Corresponding author. E-mail: tufan@zjut.edu.cn

Copyright $\odot 2020$ The Author(s). Published by Vilnius Gediminas Technical University

This is an Open Access article distributed under the terms of the Creative Commons Attribution License (https://creativecommons.org/licenses/by/4.0/), which permits unrestricted use, distribution, and reproduction in any medium, provided the original author and source are credited. 
exploration of the low industrial land price mechanism in China. The research of Wu (2007) and Zhang et al. (2017) on industrial land prices focused on interregional governmental and international competition. Wu et al. (2014) explained the causes of low industrial land prices using a "centipede game model." The other angle is an investigation of the factors that influence industrial land prices through quantitative studies. Most of these articles are based on panel data at the city level (Lin \& Ben, 2009; Jin et al., 2011; Wang et al., 2012; Zhao \& Xiao, 2012; Huang et al., 2017) and analyze the influence of economic and financing factors. Only a few of these studies base on micro data that can detect the impact of factors, such as neighborhood attributes, location attributes, and agglomeration (Lin \& Ben, 2009; Tu et al., 2017).

The previous research exploring the influence from land use regulations concentrating on land prices and residential properties (Black \& Hoben, 1985; Quigley \& Rosenthal, 2005; Glaeser \& Ward, 2009; Kok et al., 2014). However, research investigating industrial land prices, specifically the importance of land use regulations, has received little attention in China and developing countries. The context of land use regulations is also different from that in developed countries. The research conducted by $\mathrm{Fu}$ and Somerville (2001) and Brueckner et al. (2017) investigated the impact on land values. Only the paper by Han et al. (2020), based on transaction data from 2007 to 2016 that cover 286 prefectural cities, summarizes the main land use regulation instruments, including the constructed land quota, the allowed FAR and land supply restrictions and its influence on industrial land prices. However, this research matched land transaction parcels at the prefectural city level and calculated the average land price as the final value for each city. Because of the heterogeneity of land prices based on city-level data, this empirical analysis has limitations. The weakness of using average land values is that they depend heavily on actual land parcels. For example, in a city with a high percentage of land parcels in the suburban area and a city with a high percentage of land parcels in downtown areas, the former will have comparatively low land values in the end, but this will lead to distortions in the actual value.

In this paper, first, from the theoretical perspective, an integrated conceptual framework is presented to illustrate the multiple influential pathways from land use regulations to industrial land prices. In addition, accurate industrial land plot information provides powerful supplement to the existing literature to address the heterogeneity of industrial land prices by different levels of development zones, subtypes of industrial firms and land transfer types. The goal of this paper is to provide basic implications and information regarding the marketization of industrial land transfer and fundamental policy directions.

The structure of the paper is as follows: in the first section, we describe the background of land use regulations in China; the second section describes the study area and data; the third section explains the model and variables; the fourth section provides the empirical results; and the fifth section provides a discussion. In the final section, the conclusions and policy implications are presented.

\section{Background of land use regulations in China}

Before 2006, the main method for companies to purchase industrial land use rights was to negotiate with local governments, and they did not need to conduct open market transactions. The result was a low industrial land price and a large number of industrial parks, which leads to an inefficiently industrial land-use model. After the industrial output value of industrial land in China reached a peak of $2105 \mathrm{RMB} / \mathrm{m}^{2}$ in 2013 , it gradually declined. From the perspective of absorbing the employed population, the use of industrial land also continued to decline (Figure 1).

The underlying reason for the local government transfer of industrial land use rights at a very low price that did not compensate for the cost of the land is that local

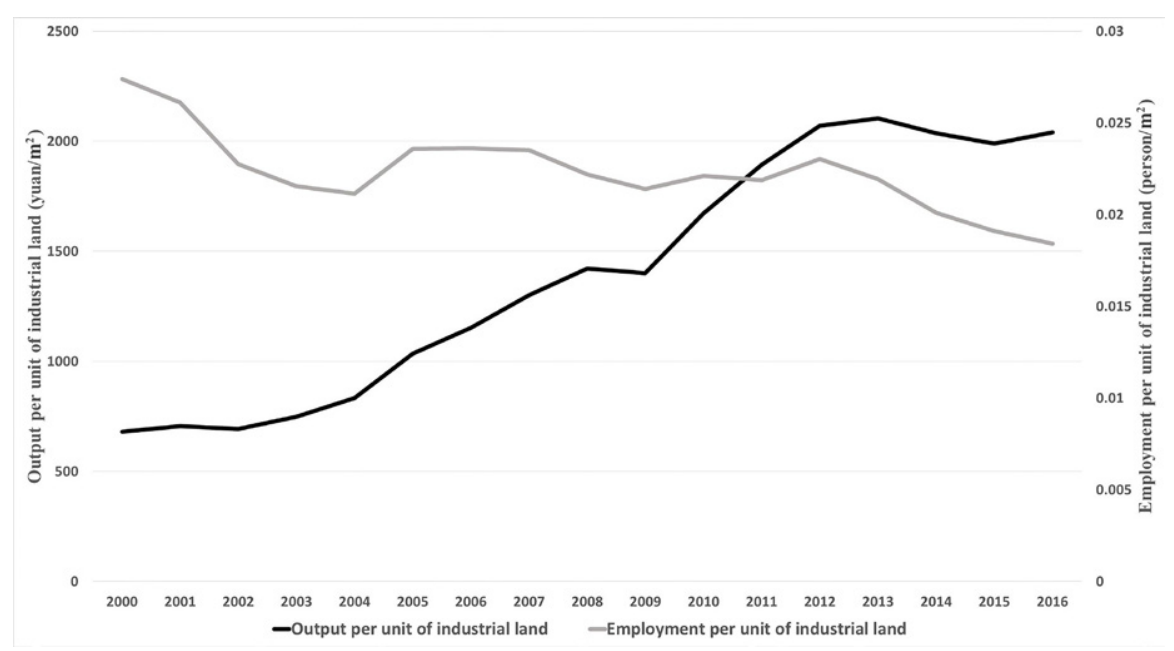

Figure 1. Industrial output and employment per unit of industrial land from 2000 to 2016 (source: National Bureau of Statistics of China, 2017; Ministry of Housing and Urban-Rural Development, P. R. China, 2017) 
governments prefer the GDP increases that industrial firms can bring. Although "promotion tournaments" have led to miraculous growth in China and served as an incentive system for local officials, this system is the root of many pressing social and economic problems (Zhou, 2007). Governmental intervention in the industrial land market offers industrial park management services and significantly influences decisions regarding the location, quantity, sale prices, and first trade-off of industrial locations (Shen \& Sun, 2012).

In 2006, the Chinese economy exhibited signs of inflation, with a GDP growth of $10.7 \%$, the fastest growth since 1995, and the fourth consecutive year of doubledigit economic growth since 2002. The central government formally and systematically introduced land policies at the end of 2006 as a macroeconomic control tool to prohibit the expansion of industrial parks at very low transferred land prices. To push for market mechanisms to allocate industrial land. The State Council specified that "industry, commerce, tourism, entertainment, and profitoriented residential land, or land that has two intended uses, must be transferred through tender, auction, or listing approaches." The new marketization mechanisms can facilitate the entry of multiple potential users into the land transfer process, thereby increasing land prices and improving future land use efficiency.

The traditional rationale for the regulation of land use in urban areas is to promote economic efficiency through the control of external effects. Although there are various approaches to government interventions in land and property markets, there is no single definition of land use regulation. Based on the industrial land regulation reform in China and the regulation tools mentioned in papers that focus on the experience of developed countries, we consider three classes of regulations: (1) policy changes that influence the financial costs faced by developers and industrial firms, (2) zoning codes that impact the conditions of industrial land transfer, and (3) industry land quotas, because the land supply is decided by the local government.

The first class of regulations is exhibited in the policy implemented at the end of 2006, which not only changed the method of industrial land transfer but also established the bottom line for the industrial land transfer price. After that, the following three land use transfer methods were utilized: auction (Pai Mai), listing (Gua Pai) and tender (Zhao Pia), in contrast with the negotiation that took place between local governments and industrial firms before 2006. An auction requires the bidder to make an open bid at a specified time and place. Usually, the highest bidder obtains the land use rights (Peng \& Liu, 2015). The difference between a listing and an auction is that a listing usually takes place for a certain period of time, such as 10 days. In contrast, auctions occur on site, and the time allotted to determine the price application and make competitive decisions is very limited. Tender involves inviting specific organizations to bid, and the final land users are determined according to the tender conditions. In many circumstances, the final bidder is not the applicant with the highest bid.

The second type of land use regulation imposes explicit limitations on available building capacity for builders; these limits include the FAR, building density and ratio of green space. The government sets zoning rules for each industrial land plot under land transfer conditions. A mandatory percentage of building density, FAR and ratio of green space is assigned in the land transfer contract between industrial firms and the local government. In addition, there is a minimum baseline FAR, building density and ratio of green space according to different industry subtypes that differs from that of commercial and residential land. In the latter situation, in most cases, maximum indicators are set, which is similar to zoning in developed countries.

The third type of land use regulation is the quota of land supply, which does not exist in many countries. Wang et al. (2010) and Han et al. (2020) illustrate how the quantity of land supply for the entire permitted area from farmland to construction land is decided. However, although the two articles explain in detail the overall land use planning approach, the annual new construction land plan, and the relationship between the two, neither article mentions the annual transfer plan. The plan ultimately determines how much actual urban land can be transferred from the government each year, including industrial, commercial, and residential land.

Figure 2 explains the relationship and interaction between the Annual Urban Land Transfer Plan (niandu tudi churang jihua), the Land Use Master Plan (tudi liyong zongti guihua) and the Annual Land Use Plan (niandu tudi liyong jihua). The Master Plan sets long-term regulations, i.e., generally between 10 and 15 years, regarding both the quantity and spatial distributions of local agricultural land and the ultimate quantities that can be converted to construction land (jianshe yongdi, referring to land for nonagricultural use). The Annual Land Use Plan is also issued by the higher-level government and based on the Master Plan. Due to the impact of economic development, the Annual Land Use Plan is not equivalent to the quotas determined by the Master Plan divided by the total number of implementation years. If the accumulation of construction exceeds the quotas in the Master Plan, the Master Plan will be reformulated. The remaining power of the local government is to draw up the Annual Urban Land Transfer Plan, which distributes the land quota by type of urban land uses, including commercial, residential, industrial, infrastructure and public facilities. This plan is based on not only how much land can be converted from agricultural land to construction land, which is determined by the Annual Land Plan, but also on the urban stock land, which is land that was converted from agricultural use in previous years and has not been for construction, as well as idle land or retransferred urban land. 


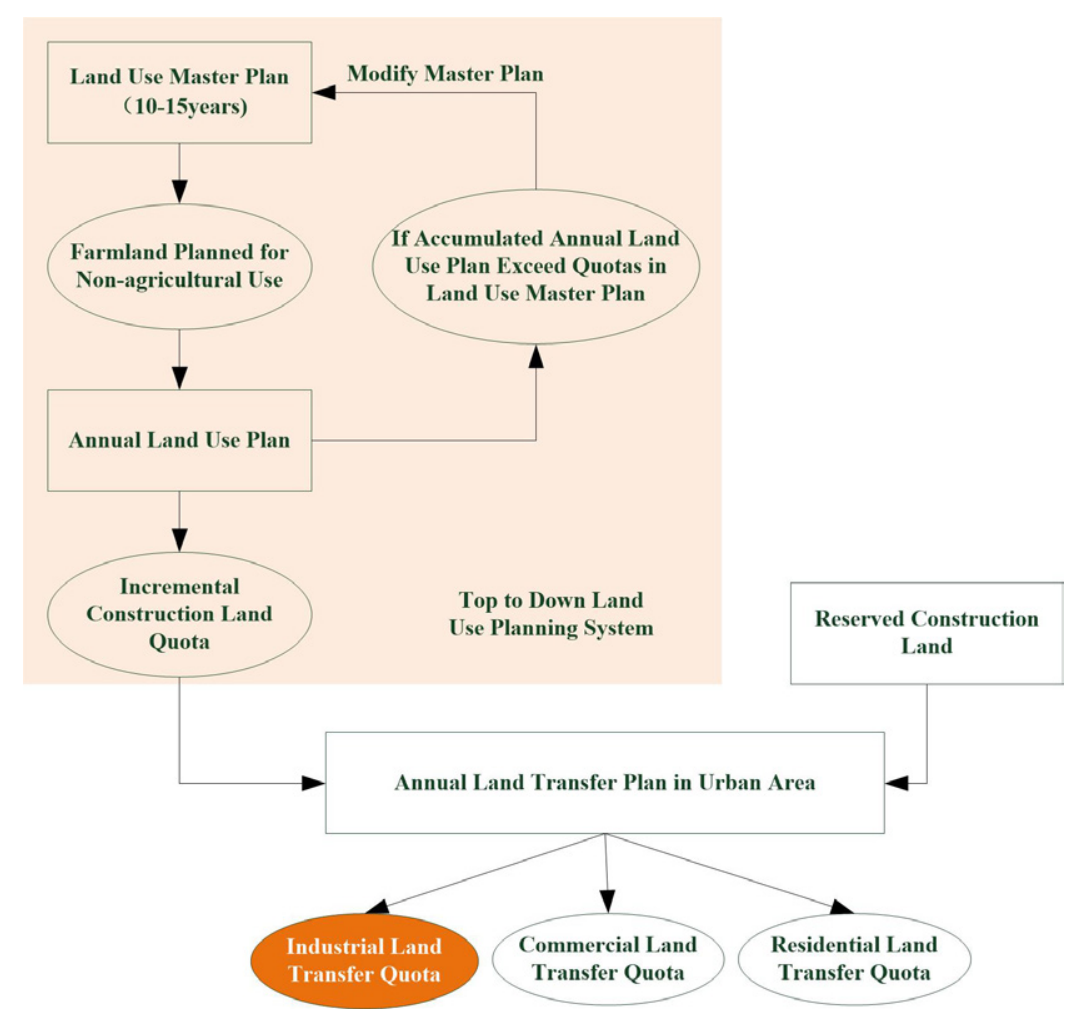

Figure 2. Formulation of industrial land quotas in the Annual Urban Land Transfer Plan

\section{Study area and data}

\subsection{Study area}

The present study analyzed the factors influencing industrial land pricing based primarily on samples of new industrial land plots supplied by the eastern coastal city of Jiaxing from 1999 to 2016. The study area, Jiaxing City, which is in Zhejiang Province, is located in the central area of the Yangtze River Delta region in Eastern China (Figure 3). Jiaxing City has an administrative area of $4275 \mathrm{~km}^{2}$ and has 2 districts, 3 cities and 2 counties, with a population of 4.65 million at the end of 2017. The GDP per capita is approximately US $\$ 14,000$ (Jiaxing Statistical Bureau, 2018).

Jiaxing was selected for the case study for two reasons. First, in terms of geographical location and economic development, Jiaxing is a good representative of cities in China's eastern area. The industrial added value of Jiaxing comprises nearly half of its GDP, and its economic development is at the average level for cities in the Yangtze River Delta region. Second, open data for industrial land plots dates back almost to 2006. The data bottleneck explains why articles that explore industrial land prices focus mostly on data after 2006. We collected data before 2006 from the Jiaxing Natural Resource and Planning Bureau. These datasets cover the period from 1999 to 2016, which broadly supplements the data on transferred industrial land plots and helps analyze changes in the industrial land transfer market over a longer period.

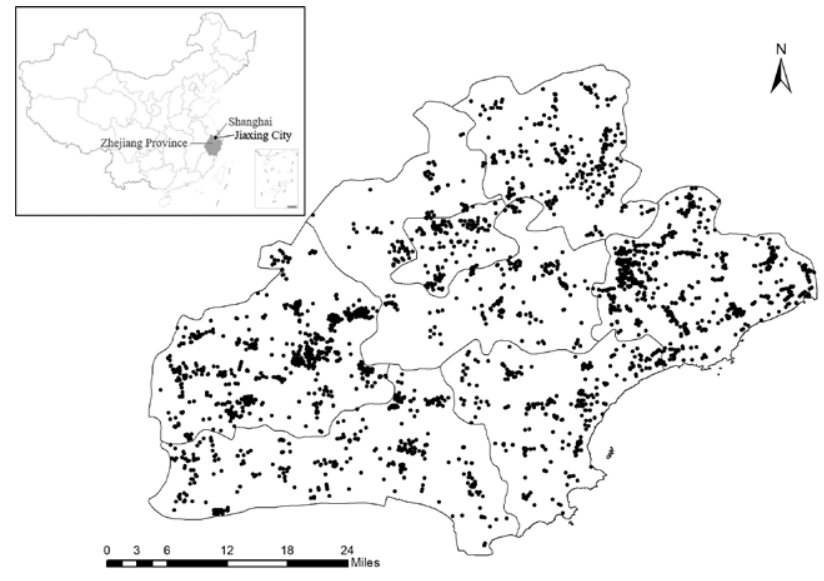

Figure 3. Location of Jiaxing City and industrial land plots obtained through transfer in Jiaxing from 1999 to 2016

\subsection{Data}

Using this dataset, we identified 9133 industrial land properties in Jiaxing City that were sold by local governments to industrial firms from 1999 to 2016 (Figure 3). The industrial land price dataset contains the price of land transferred from government to enterprises as well as the area of the land and the transfer type. In addition to the land value, information about the land location inside and outside of development zones, industry type and firm ownership type were recorded and used to deepen the research. Therefore, data with incomplete attribute information were removed from the database. After screening, the 
final dataset consisted of 6590 industrial land properties. We calculated the shortest paths to and the reachability of harbors, city centers, airports, and highways based on Baidu maps and geospatial information.

\section{Model and variables}

\subsection{Model selection}

A hedonic price estimation is probably the natural starting point for analyzing property values. However, it should be noted that hedonic pricing theory assumes that markets are perfectly competitive (Rosen, 1974). Supply in China's land market is determined by the local government. Moreover, strong competition exists among local governments to attract industrial firms through low land prices. The price of auctioned land more accurately conveys the market's signal. From 1999 to 2016, the price of listed and negotiated industrial land plots was much lower than the price of auctioned land (Figure 4). Therefore, the data do not fully meet the conditions for a hedonic model. Using the panel dataset from Han et al. (2020), the results account for approximately only $30 \%$ of the variance.

Therefore, we used a multiple linear regression model to examine the effects of land use regulations on industrial land prices. This model may be written as follows:

$$
\operatorname{LnP} P_{i}=\beta_{0}+\beta_{1} \text { LR }_{i}+\beta_{2} \text { Location }_{i}+\beta_{3} \text { Firm }_{i}+\varepsilon_{i} .
$$

In Eq. (1), the natural log of industrial land value is the dependent variable. In addition, $P_{i}$ is the price of industrial land $i ; L R_{i}$ is a group of land use regulation attributes; Location $_{i}$ is a group of location characteristics (e.g., proximity to highways, proximity to harbors, CBD); Firm $_{i}$ is the industrial firm's characteristics; $\varepsilon_{i}$ is an error term. All the numeric explanatory variables are algorithmized.

The second step is an OLS model that includes interaction terms as independent variables. The formula for the OLS model used in the current study is shown in Eq. (2). By integrating the POLICY variable and other land use regulations using the full sample and by stratifying the sample according to the type of firm ownership, develop-

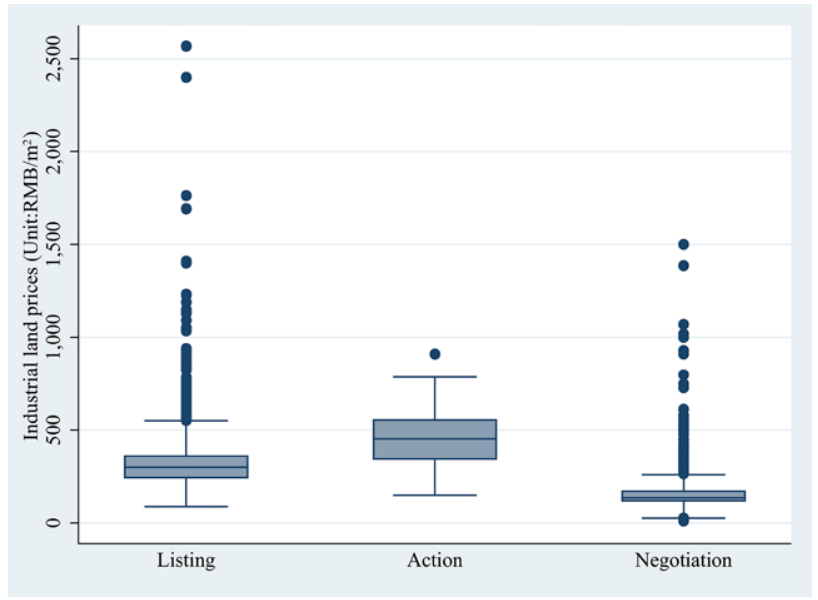

Figure 4. Comparisons of industrial land prices from 1999 to 2016 for land transferred via listing, auction, and negotiation

ment zone, and transfer method, the impacts of POLICY can be explored more comprehensively.

$$
\begin{aligned}
& \operatorname{LnP}_{i}=\beta_{0}+\beta_{1} L R_{i}+\beta_{2} \text { POLICY } \star L R_{i}+\beta_{3} \text { Location }_{i}+ \\
& \beta_{4} \text { Firm }_{i}+\varepsilon_{i} .
\end{aligned}
$$

\subsection{Variables}

The dependent variable that this study focused on was the transferred price of industrial land. The mean and median sale prices for industrial land from 1999 to 2016 were $236.37 \mathrm{RMB} / \mathrm{m}^{2}$ and $203.95 \mathrm{RMB} / \mathrm{m}^{2}$, respectively (Figure 5).

Previous studies have reported the capacity of methodologies to explain industrial land value price differentiation for different types of neighborhoods and locations (Kowalski \& Paraskevopoulos, 1990; Asabere \& Huffman, 1991; Atteberry \& Rutherford, 1993; Fehribach et al., 1993; Lockwood \& Rutherford, 1996; Tu et al., 2017). Due to the characteristics of industrial properties, the effects of environmental contamination have also received attention, and its impacts on industrial poverty values have been explored (Braimoh \& Onishi, 2007; Jackson, 2002;

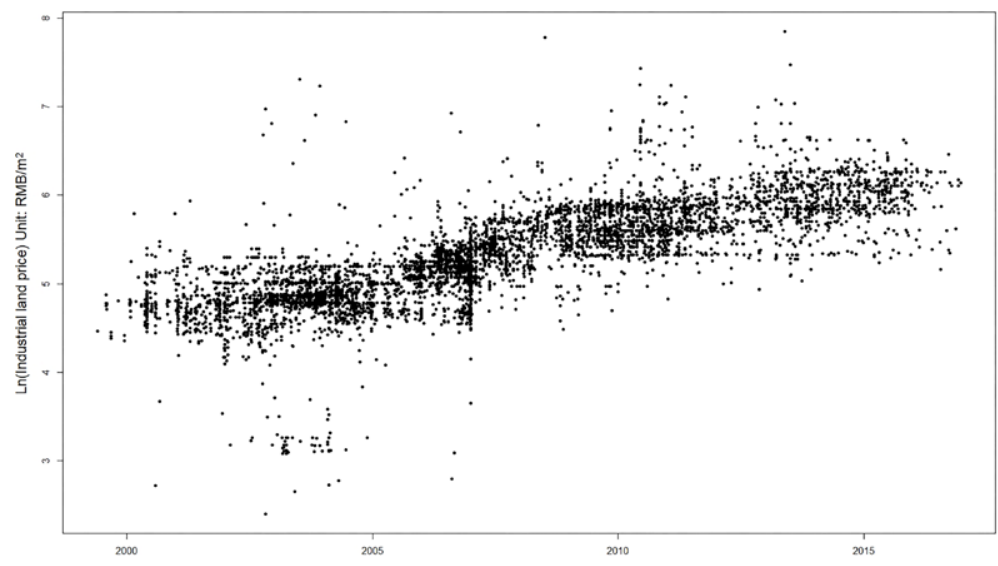

Figure 5. Scatter plot of transferred industrial land prices from 1999 to 2016 
Guntermann, 1995). The influence of building supply on the determination of industrial properties has also been investigated (Atteberry \& Rutherford, 1993; Thompson \& Tsolacos, 2001). In addition to these relationships, studies have examined the relationship between industrial property values and economic trends. Peiser (1987) found the labor agglomeration have a positive effect on industrial property values. Thompson and Tsolacos (1999) previously established macroeconomic variables that capture cyclical economic activity. Similarly, financial and monetary variables have been employed to analyze the repercussions of changes in financial market conditions, monetary policies, and expectations on industrial real estate values (Atteberry \& Rutherford, 1993; Lockwood \& Rutherford, 1996).

To verify our theoretical hypothesis, the FAR, building density, ratio of green space, annual industrial land supply and 2006 policy were selected as explanatory variables in the models, and locational attributes and enterprise attributes were used as control variables. Distances to the nearest highway, port, airport, train station and $\mathrm{CBD}$ were also considered. The accessibility of the highway, which means the number of entrances within a designated distance, was also included among the locational attributes. A number of dummy variables related to locational attributes was added for each property according to whether the property was located in a national- or provincial-level economic zone, the category of the industrial enterprise and whether the enterprise was a private, state or foreign company.

Distance to highways was calculated in two ways. First, we calculated the travel distance from the plot to the nearest expressway based on the Baidu map road network, and HIGHWAY_Nearest represents the shortest travel distance to the expressway. Second, we calculated the number of highway entrances and exits within a $10-\mathrm{km}$ radius of the land plot, with HIGHWAY_Accessibility representing the convenience of travel to the expressway.

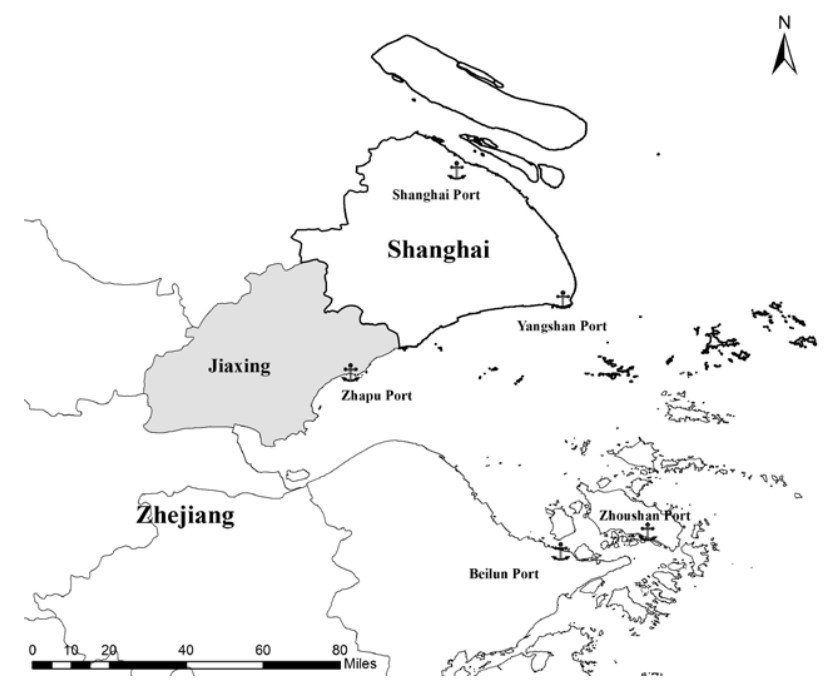

Figure 6. Location of ports in Jiaxing and nearby areas
In Jiaxing, there are five ports altogether. Zhapu harbor is located in Jiaxing. Among the other four harbors, Shanghai harbor and Yanshan harbor are in Shanghai, and Beilun harbor and Zhoushan harbor are in Zhejiang Province. All four harbors are deep-water ports that can provide international ocean transportation. Therefore, the variable PORT_Nearest measures the shortest distance to the four seaports outside Jiaxing. Meanwhile, PORT_Zha$\mathrm{pu}$ indicates the distance to Zhapu port, which covers sea transportation to other areas in China (Figure 6).

In terms of airports, although there is no airport in Jiaxing City, considering its central location in the Yangzi delta area, there are three international airports around Jiaxing City. One is Xiaoshan International Airport in Hangzhou, the capital of Zhejiang Province. The other two international airports are both in Shanghai: Hongqiao airport and Pudong airport. Pudong airport is far from Hongqiao. Therefore, the variables of AIRPORT_Xiaoshan and AIRPORT_Hongqiao indicate the distance to Xiaoshan airport and Hongqiao airport (Figure 7).

In addition, we also calculate the travel distance from the land plot to the nearest train station and CBD based on the Baidu map road network. Thus, five locational variables were used in the final analysis: PORT_Nearest, PORT_Zhapu, AIRPORT_Xiaoshan, AIRPORT_Hongqiao, TRAIN, HIGHWAY_Nearest, HIGHWAY_Accessibility, and CBD (Table 1).

\section{Results}

\subsection{The impact of land use regulations on industrial land prices}

Table 2 presents the results of this analysis. We tested for heteroskedasticity using the Breusch-Pagan test, and the fitted values of the dependent variables failed to reject the null hypothesis of homoskedasticity, thus affecting the efficiency of the estimates. Heteroskedasticity-consistent standard errors were generated to correct for the estimate

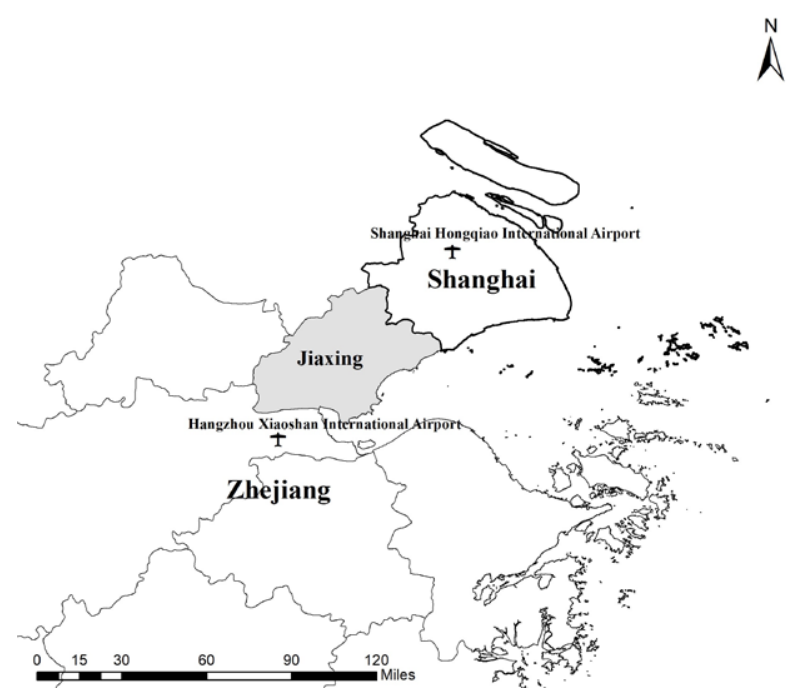

Figure 7. Location of airports in Jiaxing and nearby areas 
Table 1. The definition and description of the variables in the model

\begin{tabular}{|c|c|c|c|c|c|c|}
\hline Variable & & Definition & Mean & $\mathrm{SD}$ & Min & $\operatorname{Max}$ \\
\hline \multirow{5}{*}{$\begin{array}{l}\text { Land use } \\
\text { regulation } \\
\text { variables }\end{array}$} & DENSITY & Building density & 44.566 & 10.977 & 1 & 86 \\
\hline & FAR & Floor area ratio & 1.297 & 0.494 & 0.33 & 3.5 \\
\hline & GREEN & Percentage of green space & 21.383 & 7.229 & 0.300 & 69 \\
\hline & SUPPLY & Total industrial land supply each year & 1529.884 & 766.284 & 41.685 & 3560.562 \\
\hline & POLICY & $\begin{array}{l}\text { Indicates the end of the } 2006 \\
\text { policy implemented by the central } \\
\text { government to facilitate the market } \\
\text { mechanism in industrial land transfer }\end{array}$ & 0.429 & 0.495 & 0 & 1 \\
\hline \multirow[t]{8}{*}{$\begin{array}{l}\text { Location } \\
\text { attributes }\end{array}$} & PORT_Nearest & $\begin{array}{l}\text { The closest distance to the four } \\
\text { seaports outside Jiaxing }\end{array}$ & 116.543 & 26.074 & 70.80 & 172.7 \\
\hline & PORT_Zhapu & The distance to Zhapu Harbor & 42.171 & 20.730 & 0.3 & 83 \\
\hline & AIRPORT_Xiaoshan & The distance to the Xiaoshan Airport & 86.031 & 26.001 & 25.70 & 129.1 \\
\hline & AIRPORT_Hongqiao & The distance to the Hongqiao Airport & 94.649 & 24.376 & 51.6 & 146.7 \\
\hline & TRAIN & $\begin{array}{l}\text { The shortest travel distance to a train } \\
\text { station }\end{array}$ & 17.001 & 9.562 & 0.3 & 44.9 \\
\hline & HIGHWAY_Nearest & $\begin{array}{l}\text { The shortest travel distance to the } \\
\text { expressway }\end{array}$ & 9.436 & 4.965 & 0.1 & 26.1 \\
\hline & HIGHWAY_Accessibility & $\begin{array}{l}\text { The number of highway entrances } \\
\text { (exits) within } 10-\mathrm{km} \text { of the plot }\end{array}$ & 0.641 & 0.822 & 0 & 4 \\
\hline & CBD & The distance to the CBD & 13.241 & 8.347 & 0.2 & 68.1 \\
\hline \multirow{2}{*}{$\begin{array}{l}\text { Firm } \\
\text { attributes }\end{array}$} & AREA & Lot area & 1.642 & 2.529 & 0.008 & 65.481 \\
\hline & SCALE & Total investment & 4484.410 & 11868.890 & 1.211 & 404801.5 \\
\hline
\end{tabular}

efficiencies using White's (1980) method. The final estimates use heteroskedastic-robust forms. Model 1 is based on all control variables. Model 2 includes land use regulation variables with all control variables. In Model 3, we examine the interaction effect between policy dummies and other land use regulations to investigate how the implementation of the 2006 policy impacts the change of other land use regulations. Model 4 uses only land regulation variables, and it was compared Model 3 to determine whether there was a market difference, which indicates endogeneity. Overall, the regression exhibited satisfactory explanatory power, with adjusted $\mathrm{R}$ squared values as high as 0.607 in Model 2 and 0.609 in Model 3, indicating the goodness of fit of these models. In addition, the high $\mathrm{F}$ statistic suggests the overall significance of the estimated models. As reported, most of the explanatory variables are significant.

The results in Model 2 clearly indicate that the coefficients of most land use regulation variables, including FAR, DENSITY, GREEN (green ratio) and POLICY (change in land use policies), were positive. Each additional percentage increase of FAR and DENSITY increases the price of a parcel by $12.3 \%$ and $4.42 \%$, respectively. In contrast, the green space percentage of the land parcel area (GREEN) will have a negative relationship with industrial land price. This illustrates a preference of industrial enterprises for land plots with large available constructed lands. In terms of changes in land use policy, land prices after 2016 increased by 59.08\%, suggesting that setting the threshold price for industrial land transfer dramati- cally increased the final land transfer results. However, in Model 2, the variable SUPPLY did not significantly impact industrial land transfer prices, which may be a result of the oversupply of industrial land from the government, which is consistent with the findings of previous research (Han et al., 2020).

We now include the interaction terms in Model 3. The purpose of the Chinese government changing the industrial land transfer policy at the end of 2006 was to increase industrial land use efficiency and push for market mechanisms to allocate industrial land (partially as a strategy to cool the economy). Given this, we hypothesize that the interaction terms between the POLICY dummy and the other land use regulation variables should be significant. The result of the Model 3 regression shows that most interaction terms between POLICY and other land use regulation variables become insignificant except for the GREEN variable. This indicates that every percentage increase of the GREEN variable after 2006 will decrease the land prices by $19.81 \%$, which is lower than the $36.75 \%$ decrease for before 2006. Table 2 shows that there is no marked difference between Model 3 and Model 4, indicating that the endogeneity issue is not a serious problem.

The directions of most of the location variables were as expected and significant. Industrial land located near harbors, train stations and airports had significantly increased transfer values. The findings in Model 3 indicate that the shortest distance to the five harbors plays a significant role in increasing industrial land prices, and the highest marginal effect was $22.18 \%$. Meanwhile, a closer 
Table 2. Results of the regression model of the impact of land use regulation on industrial land price

\begin{tabular}{|c|c|c|c|c|}
\hline & Model 1 & Model 2 & Model 3 & Model 4 \\
\hline \multirow[t]{2}{*}{ lnDENSITY } & & $0.0442^{\star \star \star}$ & $0.0498^{\star * \star}$ & $0.0389^{* * *}$ \\
\hline & & $(4.776)$ & $(4.373)$ & $(3.863)$ \\
\hline \multirow[t]{2}{*}{$\operatorname{lnFAR}$} & & $0.1230^{* * *}$ & $0.2305^{\star * *}$ & $0.2397^{\star * *}$ \\
\hline & & $(6.186)$ & $(3.257)$ & $(3.331)$ \\
\hline \multirow[t]{2}{*}{ lnGREEN } & & $-0.3264^{\star \star \star}$ & $-0.3675^{\star \star \star}$ & $-0.4370^{\star \star \star *}$ \\
\hline & & $(10.068)$ & $(8.399)$ & $(10.705)$ \\
\hline \multirow[t]{2}{*}{$\operatorname{lnSUPPLY}$} & & -0.0039 & -0.0020 & -0.0042 \\
\hline & & $(0.391)$ & $(0.174)$ & $(0.353)$ \\
\hline \multirow[t]{2}{*}{ POLICY } & & $0.5908^{* * *}$ & $0.5886^{\star * *}$ & $0.6311^{\star * *}$ \\
\hline & & $(48.735)$ & $(37.201)$ & $(39.649)$ \\
\hline \multirow[t]{2}{*}{ POLICY $\cdot \operatorname{lnDENSITY}$} & & & -0.0166 & 0.0258 \\
\hline & & & $(0.889)$ & $(1.532)$ \\
\hline \multirow[t]{2}{*}{ POLICY $\ln F A R$} & & & -0.0979 & $-0.1377^{\star}$ \\
\hline & & & $(1.336)$ & $(1.849)$ \\
\hline \multirow[t]{2}{*}{ POLICY・lnGREEN } & & & $0.1694^{\star * \star}$ & $0.2277^{\star * *}$ \\
\hline & & & $(3.570)$ & $(4.713)$ \\
\hline \multirow[t]{2}{*}{ POLICY•lnSUPPLY } & & & -0.0166 & -0.0351 \\
\hline & & & $(0.657)$ & $(1.339)$ \\
\hline \multirow[t]{2}{*}{ lnPORT_Nearest } & $-0.2945^{\star \star}$ & $-0.1969^{\star}$ & $-0.2218^{\star \star}$ & \\
\hline & $(2.229)$ & $(1.913)$ & $(2.127)$ & \\
\hline \multirow[t]{2}{*}{ lnPORT_Zhapu } & $-0.0570^{* * *}$ & $-0.0871^{\star * *}$ & $-0.0874^{* * *}$ & \\
\hline & $(3.707)$ & $(7.978)$ & $(7.921)$ & \\
\hline \multirow[t]{2}{*}{ lnAIRPORT_Xiaoshan } & 0.0210 & $-0.1318^{\star \star}$ & $-0.1569^{* * *}$ & \\
\hline & $(0.307)$ & $(2.479)$ & $(2.983)$ & \\
\hline \multirow[t]{2}{*}{ lnAIRPORT_Hongqiao } & $0.3249^{\star * *}$ & 0.0535 & 0.0624 & \\
\hline & $(2.971)$ & $(0.629)$ & $(0.731)$ & \\
\hline \multirow[t]{2}{*}{ lnTRAIN } & $-0.1047^{\star * *}$ & $-0.0573^{\star * \star}$ & $-0.0543^{* * *}$ & \\
\hline & $(7.320)$ & $(4.793)$ & $(4.465)$ & \\
\hline \multirow[t]{2}{*}{ lnHIGHWAY_Nearest } & 0.0008 & -0.0045 & -0.0033 & \\
\hline & $(0.065)$ & $(0.530)$ & $(0.386)$ & \\
\hline \multirow[t]{2}{*}{ HIGHWAY_Accessibility } & $0.0497^{\star * *}$ & $0.0323^{* * *}$ & $0.0323^{* * *}$ & \\
\hline & $(5.054)$ & $(4.715)$ & $(4.735)$ & \\
\hline \multirow[t]{2}{*}{$\operatorname{lnCBD}$} & $0.0308^{* * *}$ & $-0.0385^{\star * *}$ & $-0.0424^{* * *}$ & \\
\hline & $(2.885)$ & $(4.458)$ & $(4.920)$ & \\
\hline \multirow[t]{2}{*}{$\ln \mathrm{AREA}$} & $-0.3625^{\star * *}$ & $-0.1000^{\star \star \star}$ & $-0.0938^{\star * *}$ & \\
\hline & $(30.093)$ & $(10.849)$ & $(9.390)$ & \\
\hline \multirow[t]{2}{*}{$\operatorname{lnSCALE}$} & $0.3903^{* * *}$ & $0.0980^{\star * \star}$ & $0.0928^{\star \star *}$ & \\
\hline & $(40.246)$ & $(12.296)$ & $(10.564)$ & \\
\hline \multirow[t]{2}{*}{ _cons } & $2.5927^{\star \star \star}$ & $6.9595^{\star * *}$ & $7.2727^{\star * *}$ & $6.2176^{\star * *}$ \\
\hline & $(3.761)$ & $(12.971)$ & $(13.345)$ & $(46.062)$ \\
\hline $\mathrm{N}$ & 6590 & 6590 & 6590 & 6590 \\
\hline $\mathrm{F}$ & $253.82^{\star * *}$ & $764.67^{\star * *}$ & $653.70^{* * *}$ & $1072.37^{* * *}$ \\
\hline adj. R-sq & 0.284 & 0.607 & 0.609 & 0.580 \\
\hline
\end{tabular}

Note: Absolute $t$ statistics in parentheses $={ }^{*} \mathrm{p}<0.1 ;{ }^{* *} \mathrm{p}<0.05 ;{ }^{* *} \mathrm{p}<0.01$. 
distance to Zhapu harbor, Xiaoshan airport, train station and CBD in each county increases industrial land transfer prices by approximately $8.74 \%, 15.69 \%, 5.43 \%$ and $4.24 \%$, respectively. The variable HIGHWAY_Accessibility, which measures the number of entrances to the freeway within 10 kilometers, also has a positive impact on industrial land prices. This result illustrates that accessibility to highway entrances and exits is more important than distance to the highway.

\subsection{The impact of land use regulations on industrial land prices from the perspective of land transfer type}

The government's policy goal at the end of 2006 was to reduce the proportion of negotiation transfers and increase the proportion of the other three transfer types. Figure 5 shows that the degree of land prices is completely consistent with the degree of marketization; that is, the auction price is the highest, the negotiation price is the lowest, and the listing and tender prices are close. The ratio of listed land to the full land plot after 2006 was the highest, and the proportion of land transferred by negotiation decreased significantly (Figure 8 ). Figure 4 and Figure 8 also imply that the local government does not seek the highest price during the process of industrial land transfer. Due to the high price of auctioned land, auctioning is not used as the main method of transfer. There are only 22 auctioned parcels in total. Tendering types are relatively complicated and are not widely used. Only 10 land plots were transferred from local government to industrial firms through tender from 2000 to 2017.

Table 3 shows the impact of land use regulation on industrial land prices by land transfer type. All models were significant at $p<0.05$, indicating that at least one independent variable in each model was significantly correlated with the dependent variable.

With the two transfer methods, the coefficient FAR and GREEN have significant effects. The FAR has a positive significant role in industrial land price, while the GREEN variable has the opposite effect. Meanwhile, the empirical results suggest that the sensitivity of land price
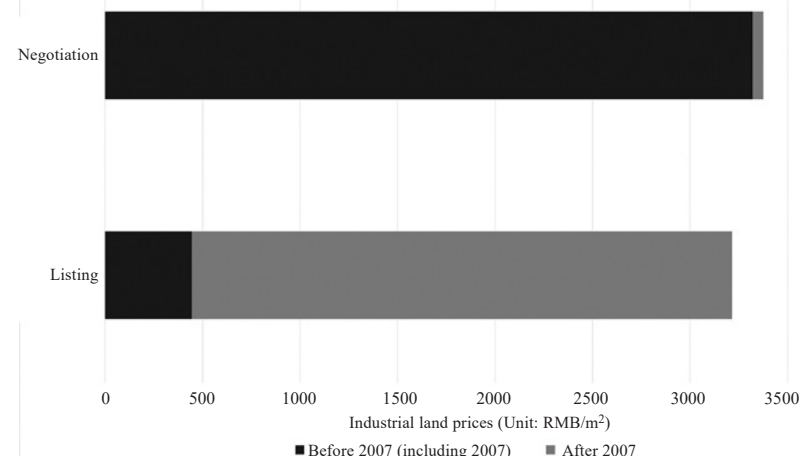

Figure 8. Comparison of industrial land by listing and negotiation types
Table 3. Results of the regression model of the impact of land use regulation on industrial land price with consideration of land transfer type

\begin{tabular}{|c|c|c|}
\hline & $\begin{array}{c}\text { TRANSFER- } \\
\text { Listing }\end{array}$ & $\begin{array}{l}\text { TRANSFER- } \\
\text { Negotiation }\end{array}$ \\
\hline \multirow[t]{2}{*}{$\operatorname{lnDENSITY}$} & 0.0179 & $0.0591^{\star * *}$ \\
\hline & $(1.319)$ & $(5.674)$ \\
\hline \multirow[t]{2}{*}{$\operatorname{lnFAR}$} & $0.2642^{\star *}$ & $0.1512^{\star *}$ \\
\hline & $(2.308)$ & $(1.992)$ \\
\hline \multirow[t]{2}{*}{$\operatorname{lnGREEN}$} & $0.1006^{*}$ & $-0.3492^{* * *}$ \\
\hline & $(1.742)$ & $(6.788)$ \\
\hline \multirow[t]{2}{*}{$\operatorname{lnSUPPLY}$} & $-0.5281^{\star * *}$ & -0.0096 \\
\hline & $(3.043)$ & $(0.854)$ \\
\hline \multirow[t]{2}{*}{ POLICY } & 0.0814 & $0.8638^{\star * \star}$ \\
\hline & $(1.561)$ & $(7.855)$ \\
\hline \multirow[t]{2}{*}{ POLICY•lnDENSITY } & 0.0217 & $0.5712^{\star *}$ \\
\hline & $(1.080)$ & $(2.452)$ \\
\hline \multirow[t]{2}{*}{ POLICY $\bullet \ln F A R$} & -0.1570 & -0.0969 \\
\hline & $(1.357)$ & $(0.493)$ \\
\hline \multirow[t]{2}{*}{ POLICY•lnGREEN } & $-0.3075^{\star * *}$ & $0.5831^{\star * *}$ \\
\hline & $(4.947)$ & $(3.168)$ \\
\hline \multirow[t]{2}{*}{ POLICY $\cdot \ln S U P P L Y$} & $0.5164^{\star * *}$ & 0.2177 \\
\hline & $(2.955)$ & $(1.391)$ \\
\hline \multirow[t]{2}{*}{ lnPORT_Nearest } & -0.0219 & $-0.5343^{\star * *}$ \\
\hline & $(0.139)$ & $(3.937)$ \\
\hline \multirow[t]{2}{*}{ lnPORT_Zhapu } & $-0.1115^{\star * *}$ & $-0.0777^{\star * *}$ \\
\hline & $(7.051)$ & $(5.329)$ \\
\hline \multirow[t]{2}{*}{ lnAIRPORT_Xiaoshan } & $-0.1123^{\star *}$ & $-0.2423^{\star * *}$ \\
\hline & $(1.994)$ & $(2.604)$ \\
\hline \multirow[t]{2}{*}{ lnAIRPORT_Hongqiao } & -0.0215 & 0.1986 \\
\hline & $(0.191)$ & $(1.473)$ \\
\hline \multirow[t]{2}{*}{$\operatorname{lnTRAIN}$} & $-0.1141^{\star \star \star}$ & 0.0117 \\
\hline & $(8.053)$ & $(0.560)$ \\
\hline \multirow[t]{2}{*}{ lnHIGHWAY_Nearest } & $-0.0394^{\star * *}$ & $0.0336^{\star * *}$ \\
\hline & $(3.721)$ & $(2.711)$ \\
\hline \multirow[t]{2}{*}{ HIGHWAY_Accessibility } & $0.0355^{\star * *}$ & $0.0241^{\star *}$ \\
\hline & $(4.268)$ & $(2.370)$ \\
\hline \multirow[t]{2}{*}{$\operatorname{lnCBD}$} & $0.0315^{\star * *}$ & $-0.1153^{* * *}$ \\
\hline & $(2.784)$ & $(8.804)$ \\
\hline \multirow[t]{2}{*}{$\ln A R E A$} & $-0.1639^{\star * *}$ & $-0.0580^{\star * *}$ \\
\hline & $(12.339)$ & $(4.210)$ \\
\hline \multirow[t]{2}{*}{ lnSCALE } & $0.1329^{* * *}$ & $0.0708^{\star * \star}$ \\
\hline & $(10.790)$ & $(6.048)$ \\
\hline \multirow[t]{2}{*}{-cons } & $9.3431^{\star * *}$ & $8.4830^{\star * *}$ \\
\hline & $(6.350)$ & (9.292) \\
\hline $\mathrm{N}$ & 3215 & 3375 \\
\hline $\mathrm{F}$ & $102.91^{\star * *}$ & $90.76^{\star * *}$ \\
\hline adj. R-sq & 0.314 & 0.273 \\
\hline
\end{tabular}

Note: Absolute $t$ statistics in parentheses $={ }^{*} \mathrm{p}<0.1 ;{ }^{* *} \mathrm{p}<0.05 ;{ }^{* *} \mathrm{p}<0.01$. 
to DENSITY levels through negotiation is more significant than that through listing, indicating heterogeneity of the stringency of DENSITY constraints. From the interaction of policies and other variables, the impact of the green space rate is the same as in the case of the entire sample.

According to the empirical results, the coefficient between land supply and industrial land price is significantly different under the listing and transfer methods. This policy significantly increased the price of the land transferred through negotiation by $86.38 \%$. However, for land plots transferred through listing, for every $1 \%$ increase in land supply before 2006, industrial land prices decrease by $52.81 \%$, and there was only a $1 \%$ decrease after 2006 . This is a very interesting finding that implies that the function of listing changed after 2006, indicating that listing is not a perfect tool for promoting industrial land marketization and suggesting the need to explore why this form of open transfer did not perform as predicted.

\subsection{The impact of land use regulations on industrial land prices from the perspective of firm ownership}

Figure 9 shows the distribution of land prices among industrial enterprises with different ownership attributes. Private enterprises have the highest average price of industrial land and the largest difference; state-owned enterprises have the lowest average price and the smallest difference; and foreign companies are in the middle.

Table 4 shows the impact of land regulation on industrial enterprises by ownership attributes. Most of the characteristics of land regulation have a significant impact on private and foreign companies. Both FAR and POLICY increase the price of industrial land under these two ownership types, and the green space rate has a negative impact. In contrast, state-owned enterprises are not obvious for most of the land regulatory characteristics. A significant effect is seen for only the explanatory variable of building density, and the positive impact is also different from that

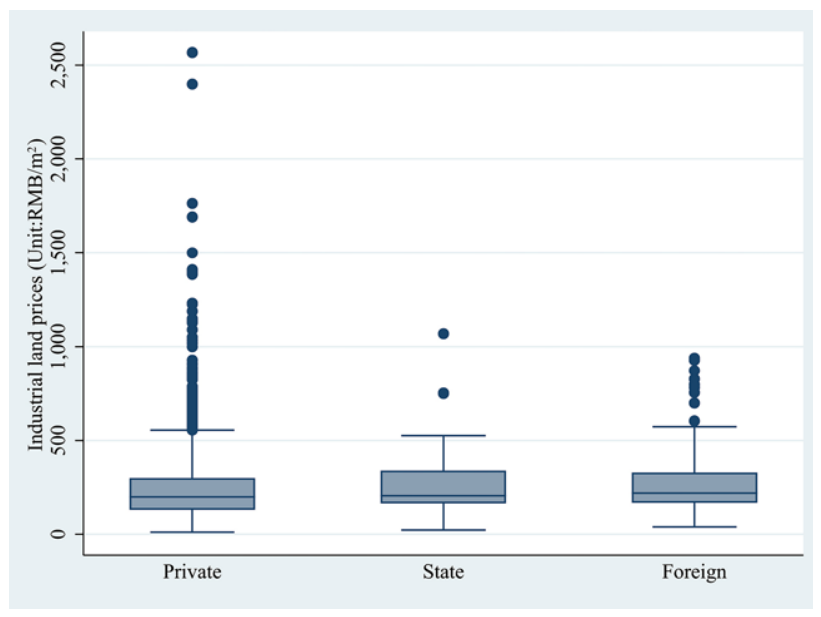

Figure 9. Comparison of industrial land prices by ownership type
Table 4. Results of the regression model of the impact of land use regulation on industrial land price by ownership type

\begin{tabular}{|c|c|c|c|}
\hline & $\begin{array}{c}\text { Private- } \\
\text { owned }\end{array}$ & $\begin{array}{l}\text { State- } \\
\text { owned }\end{array}$ & $\begin{array}{l}\text { Foreign- } \\
\text { owned }\end{array}$ \\
\hline \multirow[t]{2}{*}{ lnDENSITY } & $0.0566^{* * *}$ & $0.1559^{* * *}$ & -0.0258 \\
\hline & $(4.584)$ & $(3.544)$ & $(1.020)$ \\
\hline \multirow[t]{2}{*}{$\operatorname{lnFAR}$} & $0.2027^{\star * *}$ & 1.0600 & $0.1993^{\star}$ \\
\hline & $(2.784)$ & $(1.208)$ & $(1.737)$ \\
\hline \multirow[t]{2}{*}{ lnGREEN } & $-0.3899^{* * *}$ & -0.1222 & $-0.1333^{\star}$ \\
\hline & $(7.954)$ & $(0.477)$ & $(1.941)$ \\
\hline \multirow[t]{2}{*}{$\operatorname{lnSUPPLY}$} & -0.0044 & -0.1650 & $0.0575^{\star}$ \\
\hline & $(0.370)$ & $(1.453)$ & $(1.662)$ \\
\hline \multirow[t]{2}{*}{ POLICY } & $0.6093^{* * *}$ & 0.2775 & $0.5147^{\star \star \star}$ \\
\hline & $(36.026)$ & (1.528) & $(15.887)$ \\
\hline \multirow[t]{2}{*}{ POLICY•lnDENSITY } & -0.0294 & -0.2488 & $0.0811^{\star * \star}$ \\
\hline & $(1.331)$ & $(0.982)$ & $(2.766)$ \\
\hline \multirow{2}{*}{ POLICY $\cdot \operatorname{lnFAR}$} & -0.0877 & -0.7008 & -0.0324 \\
\hline & $(1.158)$ & $(0.797)$ & $(0.257)$ \\
\hline \multirow[t]{2}{*}{ POLICY•lnGREEN } & $0.1727^{* * *}$ & -0.3246 & 0.1119 \\
\hline & $(3.253)$ & $(1.163)$ & (1.333) \\
\hline \multirow[t]{2}{*}{ POLICY•lnSUPPLY } & 0.0042 & 0.0155 & $-0.1153^{\star}$ \\
\hline & $(0.152)$ & $(0.071)$ & $(1.773)$ \\
\hline \multirow[t]{2}{*}{ lnPORT_Nearest } & $-0.2076^{\star}$ & 1.1404 & -0.5020 \\
\hline & $(1.811)$ & $(0.921)$ & $(1.423)$ \\
\hline \multirow[t]{2}{*}{ lnPORT_Zhapu } & $-0.0877^{* * *}$ & $-0.2818^{\star}$ & $-0.1031^{\star * \star}$ \\
\hline & $(6.964)$ & $(1.868)$ & $(3.381)$ \\
\hline \multirow{2}{*}{$\begin{array}{l}\text { InAIRPORT_ } \\
\text { Xiaoshan }\end{array}$} & $-0.1527^{\star *}$ & -0.4969 & -0.1416 \\
\hline & $(2.562)$ & (1.118) & $(1.277)$ \\
\hline \multirow{2}{*}{$\begin{array}{l}\text { lnAIRPORT_ } \\
\text { Hongqiao }\end{array}$} & 0.0322 & -1.3475 & $0.4752^{\star}$ \\
\hline & $(0.335)$ & $(1.476)$ & $(1.873)$ \\
\hline \multirow[t]{2}{*}{ lnTRAIN } & $-0.0541^{* * *}$ & -0.0153 & $-0.0996^{* * *}$ \\
\hline & $(3.867)$ & $(0.116)$ & $(4.325)$ \\
\hline \multirow{2}{*}{$\begin{array}{l}\text { lnHIGHWAY_ } \\
\text { Nearest }\end{array}$} & 0.0043 & -0.1084 & $-0.0638^{\star * \star}$ \\
\hline & $(0.471)$ & (1.597) & $(2.607)$ \\
\hline \multirow{2}{*}{$\begin{array}{l}\text { HIGHWAY_ } \\
\text { Accessibility }\end{array}$} & $0.0301^{\star * *}$ & -0.0349 & $0.0263^{\star}$ \\
\hline & $(3.904)$ & $(0.743)$ & $(1.811)$ \\
\hline \multirow[t]{2}{*}{$\ln C B D$} & $-0.0516^{* * *}$ & -0.0346 & 0.0172 \\
\hline & $(5.346)$ & $(0.693)$ & $(0.958)$ \\
\hline \multirow[t]{2}{*}{$\ln A R E A$} & $-0.1012^{\star * *}$ & $-0.1570^{\star *}$ & $-0.0819^{\star * *}$ \\
\hline & $(8.949)$ & $(2.145)$ & $(4.431)$ \\
\hline \multirow[t]{2}{*}{$\operatorname{lnSCALE}$} & $0.1004^{* * *}$ & $0.1651^{\star * *}$ & $0.0781^{\star * \star}$ \\
\hline & $(9.890)$ & $(3.165)$ & $(5.075)$ \\
\hline \multirow[t]{2}{*}{ _cons } & $7.3354^{* * *}$ & $9.0575^{\star *}$ & $6.1224^{\star * *}$ \\
\hline & (11.996) & $(2.243)$ & $(4.815)$ \\
\hline $\mathrm{N}$ & 5730 & 101 & 759 \\
\hline$F$ & $562.74^{* * *}$ & $68.00^{* * *}$ & $76.85^{* * *}$ \\
\hline adj. R-sq & 0.612 & 0.615 & 0.614 \\
\hline
\end{tabular}

Note: Absolute $t$ statistics in parentheses $={ }^{*} \mathrm{p}<0.1 ;{ }^{* *} \mathrm{p}<0.05$; ${ }^{* *} \mathrm{p}<0.01$. 
in the entire sample. The nonmarketization of industrial land acquired by state-owned enterprises is strongly confirmed. From the interaction of land policies and other land regulations, for private enterprises, the correlation coefficient of the negative impact of green space rates on prices after 2006 has decreased, while the correlation coefficient of the positive impact of land supply on prices of foreign-owned enterprises has also decreased.

\subsection{The impact of land use regulations on industrial land prices from the perspective of development zones}

As seen from Figure 10, the industrial land price in the national development zone is the highest, followed by those in the provincial development zone. The development zone will impact the prices of industrial enterprises. To attract enterprises, the development zones will choose enterprises according to their goals, which will result in a selection effect (Sun et al., 2020). For example, the national development zone will focus more on technologyintensive enterprises and innovative industrial enterprises. High-level development zones also tend to have better regional locations. Therefore, industrial enterprises in high-level development zones can bear relatively higher land costs. At the same time, to attract enterprises, the development zone will also introduce preferential policies, including tax policies and land policies.

The empirical results in Table 5 show that compared to national and provincial development zones, other industrial plots are more sensitive to variables in land regulation, including FAR, DENSITY, GREEN and POLICY, possibly because the enterprises in the national and provincial development zones are more homogeneous. Therefore, enterprises outside the development zones are more sensitive to changes in indicators related to land use regulations. Compared with provincial development zones, the policy of 2006 increased the price of industrial land in national development zones more.

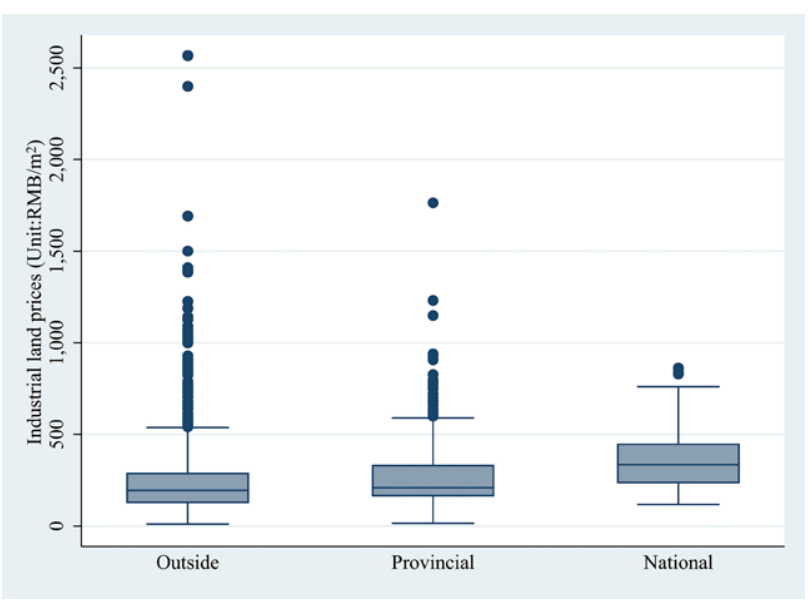

Figure 10. Comparisons of industrial firms in national and provincial development zones and other areas
Table 5. Results of the regression model of the impact of land use regulation on industrial land price by development zone

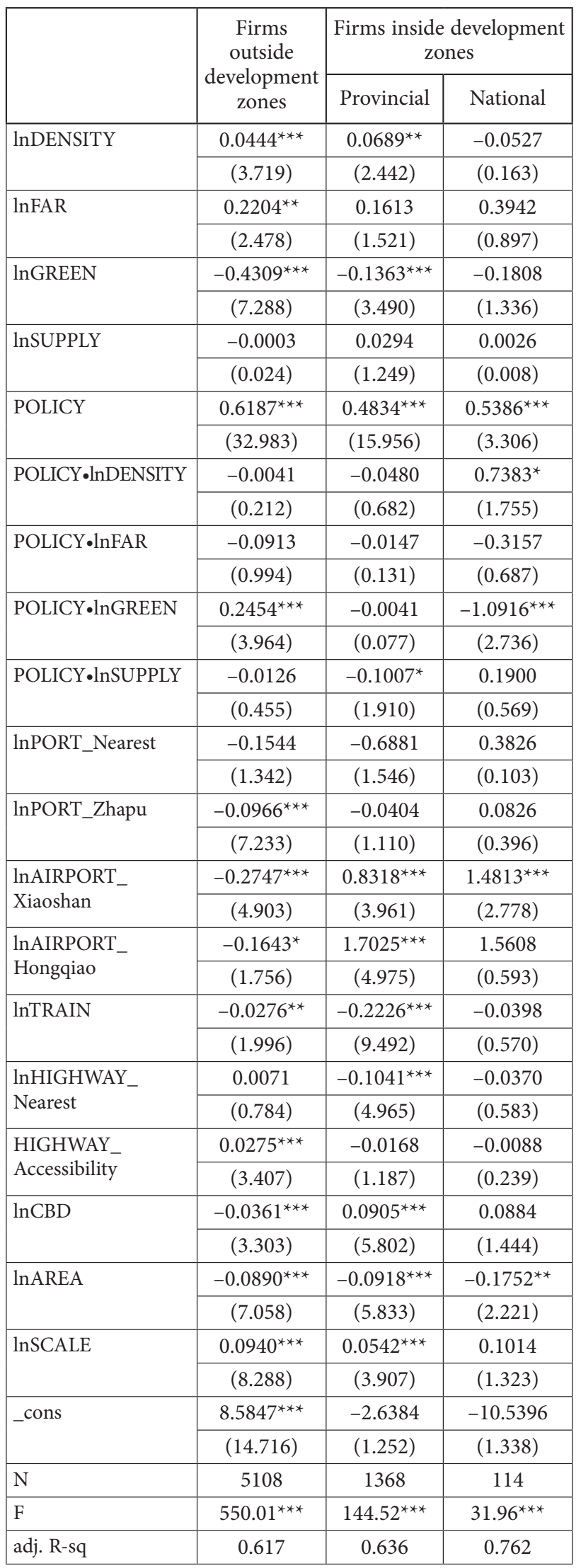

Note: Absolute $t$ statistics in parentheses $={ }^{*} \mathrm{p}<0.1 ;{ }^{* *} \mathrm{p}<0.05 ;{ }^{* *} \mathrm{p}<0.01$. 


\section{Discussion}

China's industrial land transfer model is very different from that of developed countries, and the context of land regulation is also inconsistent with that of developed countries. Analyzing the factors that influence industrial land prices over a longer period of time can help improve the understanding of the mechanism behind land price. Although the goal of reforming land use regulation is to promote the process of marketization and help increase the price and output efficiency of industrial land, the operating mechanism behind industrial land transfer is the "game" between the central and local governments, which is reflected in the results of the OLS model.

1. Limited effects of industrial land policy reform.

Although the policy change in 2006 that promoted marketization of industrial land prices had significant positive effects, the results should be interpreted carefully. Listings as the recommended public and marketized tool seems to be working, given the number of land plots transferred through listings after 2006 rising dramatically, by $86 \%$. However, through interaction analysis, the price increase in listed transferred industrial land after 2006 was insignificant. A deep investigation revealed that, although listings represented the recommended type of open market transfer, the actual process was not open. Before publicly listing land, the government still negotiated with the intended industrial firm to determine the listing conditions, including the price. The listing conditions were then set to prohibit other companies from participating in the listing process.

The other important finding is that for listed sites, the decrease in the yearly land supply before the implementation of the policy promoted a significant price increase of $53 \%$, but this increase declined to $1 \%$ after 2006 . The findings indicate that the industrial land policy reform increased industrial land prices by setting a minimum bottom line. However, in terms of promoting a market pricing mechanism, the effects were slight. The interaction effects between policy and the FAR, building density, and green space ratio show that only the interaction with the green space ratio had effects for the subtypes of listed land. The price of industrial land increased by $19.81 \%$ with each $1 \%$ decrease in the green space ratio indicator.

2. Slightly influence of land supply on industrial land price.

For the entire sample, the land supply did not affect the price, which is inconsistent with the basic pricing principle under the market mechanism, because of the oversupply of industrial land. Regarding the subsamples, the increase in the supply scale after 2006 only reduced prices by $1 \%$, far below the $21 \%$ impact of the green ratio on prices. Overall, foreign-owned companies were more sensitive to land supply quantity than other types of companies.

3. The effect of zoning code and location attributes in relation to industrial land prices.

The FAR, building density and greening rate had a very obvious effect on land prices. Among these three indicators, the greening ratio had the greatest impact on the land value, followed by the FAR. Among zoning codes, the FAR and the ratio of green space affect privately and foreign-owned land. In the subtype of development zones, enterprises outside development zones show strong land price sensitivity to most location attributes, compared with insensitivity of land plots in national and provincial industrial zones. It is possible that the firms that are located nationally and provincial park are more qualified, which is reflected in part by the higher prices of plots in these location than plots outside the parks. From the firms' side, they prefer policy incentives such as tax deductions, more convenient government services and agglomeration effects in national and provincial-level industrial zones. Location factors have a significant impact on private and foreign companies, but state-owned enterprises are insensitive to most indicators.

\section{Conclusions}

The present study focused on the impact of land use regulations on industrial land prices. Micro data of 6590 industrial land plots from 1999 to 2016 in Jiaxing City, Zhejiang Province were used. OLS models were used to analyze the impacts of land use regulations on industrial land prices. The contributions of this study are as follows: (1) Although some articles have analyzed the impacts of land use regulations on residential property values, research investigating determinants of industrial land prices, specifically from the perspective of land use regulations, has received limited attention. (2) Different from the literature addressing land use regulations, most in developed countries, our study examined three types of land use regulations, including policy to promote land use efficiency and industrial land transfer marketization, zoning codes that impact conditions in industrial land transfer, and the quota of industry land supply each year. (3) This study not only examined land use regulations but also heterogeneity from the perspective of land transfer type, ownership of industrial firms, and development zones.

The targeted land policy was implemented at the end of 2006 to promote more efficient land use and industrial land marketization. Although it is the policy very significantly increased the industrial land prices based on the whole dataset, it had a limited effect on industrial land that was transferred through listing, which was the main transfer method after 2006. It implied that the policy only raises the lowest threshold for transferred land prices. Combined with the result that the land supply only slightly decreased the transfer price of listed land after 2006, this shows that the industrial land market has not developed a mature market-oriented mechanism. The research reveals that industrial land quotas may be overly high. Among zoning variables, the GREEN indicator was the impact factor with the greatest value for industrial land, followed by FAR and DENSITY. Moreover, the results imply that the effect of land use regulations varies among land transfer types, firm ownership types and development zones. Land use regulation instruments had a significant impact 
on private and foreign companies. In contrast, impacts on state-owned enterprises were not obvious for most of the land regulation characteristics. The impact of land use regulation instruments was considerably higher for land plots outside national and provincial development zones.

The particular findings in this paper are significant in both theoretical and empirical terms and can be attributed to the modification of land use regulatory tools and promote the efficient use of industrial land ( $\mathrm{Li}$ et al., 2019a). Although industrial land differs from residential land and commercial land, reducing direct governmental intervention and promoting transparent, competitive procedures will still benefit efficient land management (Kaganova et al., 2008). It is necessary not only to change the method of industrial land transfer from negotiation to the more open and transparent methods of listing and auction type but also to reduce the "hidden" tendency threshold on the listing conditions, which holds the key for mature market mechanisms. It is well known that the land supply quota plays an important role in meeting the demands of industrial firms and should be carefully designed. A forecasting model is recommended to help estimate the effect of planning policy (Hui \& Ho, 2003). An experiment involving the RBF neural network model has been designed to predict reasonable industrial demand and link it to reasonable supply (Li et al., 2019b). In the meantime, FAR, DENSITY and GREEN indicators should be modified more scientifically and in line with industrial categories.

This study discussed the impact of land use regulations on industrial land prices. This provides a new perspective for understanding the system of land use regulation in developing countries, which is different from those in developed countries. However, this study has some shortcomings. This study analyzed this relationship only based on the OLS model, and a spatial econometric model may be another choice for future researchers to control for the spatial autocorrelation of land prices. Moreover, in this study, the data on tender- and auction-transferred land plots are limited, and further studies should attempt to include more samples to deepen our understanding.

\section{Funding}

This work was supported by the China National Office for Philosophy and Social Science under Grant 17BGL257; Zhejiang Provincial Natural Science Foundation under Grant LY18G030042.

\section{Author contributions}

Fan Tu conceived the study and were responsible for the design framework, methodology and the first draft of the article. Fan Tu and Shuangling Zou were responsible for the development of the data analysis and data interpretation. Shuangling Zou and Ran Ding were responsible for data collection and visualization.

\section{Disclosure statement}

Authors do not have any competing financial, professional, or personal interests from other parties.

\section{References}

Asabere, P. K., \& Huffman, F. E. (1991). Zoning and industrial land values: the case of Philadelphia. Real Estate Economics, 19(2), 154-160. https://doi.org/10.1111/1540-6229.00547

Atteberry, W. L., \& Rutherford, R. C. (1993). Industrial real estate prices and market efficiency. Journal of Real Estate Research, 8(3), 377-385. https://www.jstor.com/stable/44095452

Black, J. T., \& Hoben, J. E. (1985). Land price inflation and affordable housing. Urban Geography, 6(1), 27-47. https://doi.org/10.2747/0272-3638.6.1.27

Braimoh, A. K., \& Onishi, T. (2007). Spatial determinants of urban land use change in Lagos, Nigeria. Land Use Policy, 24(2), 502-515. https://doi.org/10.1016/j.landusepol.2006.09.001

Brueckner, J. K., Fu, S., Gu, Y., \& Zhang, J. (2017). Measuring the stringency of land use regulation: the case of China's building height limits. Review of Economics and Statistics, 99(4), 663-677. https://doi.org/10.1162/REST_a_00650

Callahan, M. F. (2017). Using transactional and spatial data to determine drivers of industrial land value. Massachusetts Institute of Technology, Boston. https://dspace.mit.edu/handle/1721.1/113483

Fehribach, F., Ronald, R., \& Mark, E. (1993). An analysis of the determinants of industrial property valuation. Journal of Real Estate Research, 8(3), 365-376. https://www.jstor.com/ stable/44095451

Fu, Y., \& Somerville, C. T. (2001). Site density restrictions: measurement and empirical analysis. Journal of Urban Economics, 49(2), 404-423. https://doi.org/10.1006/juec.2000.2200

Glaeser, E. L., \& Ward, B. A. (2009). The causes and consequences of land use regulation: evidence from Greater Boston. Journal of Urban Economics, 65(3), 265-278.

https://doi.org/10.2139/ssrn.936351

Guntermann, K. (1995). Sanitary landfills, stigma and industrial land values. Journal of Real Estate Research, 10(5), 531-542. http://pages.jh.edu/jrer/papers/pdf/past/vol10n05/v10p531.pdf

Han, W., Zhang, X., \& Zheng, X. (2020). Land use regulation and urban land value: evidence from China. Land Use Policy, 92, 104432. https://doi.org/10.1016/j.landusepol.2019.104432

Huang, J. S., Chen, L. G., Zhang, Y. Y., \& Zhao, A. D. (2017). Research on the relationship between local government economic behavior and industrial land price under different industrial structure. Industrial Economics Research, 3, 81-90 (in Chinese). https://doi.org/10.13269/j.cnki.ier.2017.03.007

Hui, E. C. M., \& Ho, V. S. M. (2003). Does the planning system affect housing prices? Theory and with evidence from Hong Kong. Habitat International, 27(3), 339-359. https://doi.org/10.1016/S0197-3975(02)00042-5

Jackson, T. O. (2002). Environmental contamination and industrial real estate prices. Journal of Real Estate Research, 23(1-2), 179-200. https://www.researchgate.net/publication/5142156

Jin, X. B., Zhou, Y. K., Chang, C., \& Xu, G. X. (2011). An evaluation on industrial land prices based on land marketization. Resources Science, 33(2), 302-307. http://en.cnki.com.cn/ Article_en/CJFDTotal-ZRZY201102019.htm

Kaganova, O., Akmatov, A., \& Undeland, C. (2008). Introducing more transparent and efficient land management in post-so- 
cialist cities: lessons from Kyrgyzstan. International Journal of Strategic Property Management, 12(3), 161-181.

https://doi.org/10.3846/1648-715X.2008.12.161-181

Kok, N., Monkkonen, P., \& Quigley, J. M. (2014). Land use regulations and the value of land and housing: an intra-metropolitan analysis. Journal of Urban Economics, 81(1), 136-148. https://doi.org/10.1016/j.jue.2014.03.004

Kowalski, J. G., \& Paraskevopoulos, C. C. (1990). The impact of location on urban industrial land prices. Journal of Urban Economics, 27(1), 16-24. https://doi.org/10.1016/0094-1190(90)90021-E

Li, C., Gao, X., He, B. J., Wu, J., \& Wu, K. (2019a). Coupling coordination relationships between urban-industrial land use efficiency and accessibility of highway networks: evidence from Beijing-Tianjin-Hebei urban agglomeration, China. Sustainability, 11(5), 1446. https://doi.org/10.3390/su11051446

Li, C., Gao, X., Wu, J., \& Wu, K. (2019b). Demand prediction and regulation zoning of urban-industrial land: evidence from Beijing-Tianjin-Hebei urban agglomeration, China. Environmental Monitoring and Assessment, 191(7), 412. https://doi.org/10.1007/s10661-019-7547-4

Lin, S. W., \& Ben, T. M. (2009). Impact of government and industrial agglomeration on industrial land prices: a Taiwanese case study. Habitat International, 33, 412-418. https://doi.org/10.1016/j.habitatint.2009.01.001

Lockwood, L. J., \& Rutherford, R. C. (1996). Determinants of industrial property value. Real Estate Economics, 24(2), 257272. https://doi.org/10.1111/1540-6229.00690

Ministry of Housing and Urban-Rural Development, P. R. China. (2017). China urban and rural construction statistical yearbook. China Planning Press.

National Bureau of Statistics of China. (2017). China statistical yearbook. China Statistics Press.

Peiser, R. B. (1987). The determinants of nonresidential urban land values. Journal of Urban Economics, 22(3), 340-360. https://doi.org/10.1016/0094-1190(87)90032-5

Peng, Y., \& Liu, X. (2015). Bidding decision in land auction using prospect theory. International Journal of Strategic Property Management, 19(2), 186-205. https://doi.org/10.3846/1648715X.2015.1047914

Quigley, J. M., \& Rosenthal, L. A. (2005). The effects of land use regulation on the price of housing: what do we know? What can we learn? Cityscape, 8(1), 69-137. http://urbanpolicy. berkeley.edu/pdf/QR2005.pdf

Rosen, S. (1974). Hedonic prices and implicit markets: product differentiation in pure competition. Journal of Political Economy, 82(1), 34-55. https://doi.org/10.1086/260169

Saz-Salazar, S. D., \& Leandro, G. M. (2005). Public provision versus private provision of industrial land: a hedonic approach. Land Use Policy, 22(3), 215-223.

https://doi.org/10.1016/j.landusepol.2004.05.002
Shen, X., \& Sun, X. (Eds.). (2012). Untying the land knot: making equitable, efficient, and sustainable use of industrial and commercial land. The World Bank.

https://doi.org/10.1596/978-0-8213-8970-6

Sun, Y. F., Ma, A. B., Su, H. R., Su, S. L., Chen, F., Wang, W., \& Weng, M. (2020). Does the establishment of development zones really improve industrial land use efficiency? Implications for China's high-quality development policy. Land Use Policy, 90, 104265. https://doi.org/10.1016/j.landusepol.2019.104265

Thompson, B., \& Tsolacos, T. (1999). Rent adjustments and forecasts in the industrial market. Journal of Real Estate Research, $17(2), 151-167$.

Thompson, B., \& Tsolacos, T. (2001). Industrial land values a guide to future markets? Journal of Real Estate Research, 21(1-2), 55-76.

Tu, F., Ge, J. W., Zhong, Q., \& Liu, D. X. (2017). Determinants of industrial land price in the process of land marketization reform in China. China Land Science, 31(12), 33-41.

Wang, H., Tao, R., Wang, L. L., \& Su, F. B. (2010). Farmland preservation and land development rights trading in Zhejiang, China. Habitat International, 34(4), 454-463. https://doi.org/10.1016/j.habitatint.2009.12.004

Wang, J. T., Cao, Q. F., \& Tian, S. Y. (2012). Industrial agglomeration, government intervention and industrial land prices: an empirical study on 35 Cities in China. China Land Science, 26(9), 12-20. https://doi.org/10.13708/j.cnki.cn11-2640.2012.09.008

White, H. (1980). A heteroskedasticity-consistent covariance matrix estimator and a direct test for heteroskedasticity. Econometrica: Journal of the Econometric Society, 48(4), 817-838. https://www.jstor.com/stable/1912934

Wu, Y. Z., Zhang, X. L., Skitmore, M., Song, Y., \& Hui, E. C. M. (2014). Industrial land price and its impact on urban growth: a Chinese case study. Land Use Policy, 36, 199-209. https://doi.org/10.1016/j.landusepol.2013.08.015

$\mathrm{Wu}, \mathrm{Y}$. Z. (2007). On regional equilibrium of industrial land price and management strategy based on game theory. Journal of Zhejiang University (Humanities and Social Sciences), 37(4), 124-133. http://en.cnki.com.cn/Article_en/CJFDTotalZJDX200704018.htm

Zhang, X. L., Lin, Y. L., Wu, Y. Z., \& Skitmore, M. (2017). Industrial land price between China's Pearl River Delta and Southeast Asian regions: competition or coopetition? Land Use Policy, 61, 575-586. https://doi.org/10.1016/j.landusepol.2016.12.011

Zhao, S., \& Xiao, X. J. (2012). Analysis on the land price factors in the context of macro-level framework. China Land Science, 26(9), 4-12. https://doi.org/10.13708/j.cnki.cn11-2640.2012.09.007

Zhou, L. A. (2007). Governing China's local officials: an analysis of promotion tournament model. Economic Research Journal, 7(36), 36-50. http://en.cnki.com.cn/Article_en/CJFDTotalJJYJ200707006.htm 